\title{
Genetic variability of papaya lethal yellowing virus isolates from Ceará and Rio Grande do Norte states, Brazil
}

\author{
Cleidiane B. Daltro ${ }^{1}$, Álvaro J. Pereira ${ }^{2 *}$, Renan S. Cascardo ${ }^{2}$, Poliane Alfenas-Zerbini ${ }^{3}$ José Evando A. \\ Bezerra-Junior ${ }^{4 \#}$, José Albérsio A. Lima ${ }^{4}$, Francisco Murilo Zerbini² \& Eduardo C. Andrade ${ }^{5}$
}

${ }^{1}$ Centro de Ciências Agrárias, Ambientais e Biológicas, Universidade Federal do Recôncavo da Bahia, Cruz das Almas, BA, 44380-000, Brazil; ${ }^{2}$ Departamento de Fitopatologia/BIOAGRO, Universidade Federal de Viçosa, Viçosa, MG, 36570000, Brazil; ${ }^{3}$ Departamento de Microbiologia/BIOAGRO, Universidade Federal de Viçosa, Viçosa, MG, 36570-000, Brazil; ${ }^{4}$ Departamento de Fitotecnia, Universidade Federal do Ceará, Fortaleza, CE, 60451-970, Brazil; ${ }^{5}$ Embrapa Mandioca e Fruticultura, Cruz das Almas, BA, 44380-000, Brazil

Author for correspondence: Francisco Murilo Zerbini, e-mail: zerbini@ufv.br

\begin{abstract}
The papaya (Carica papaya) is a fruit crop of great economic importance throughout the Brazilian northeast, which is responsible for $60 \%$ of the national output. Papayas in the states of Ceara and Rio Grande do Norte are affected by lethal yellowing disease, caused by papaya lethal yellowing virus (PLYV). Previous work suggested that PLYV is a putative sobemovirus. To assess the genetic variability of PLYV, foliar samples were collected in October 2008 and October 2009 in commercial fields from Ceará and Rio Grande do Norte states, and total RNA was extracted. Specific primers based on the sequence of a previously characterized PLYV isolate were used for the RT-PCR-based amplification of a 900 bp fragment corresponding to the central region of the viral genome. Fragments from 21 viral isolates were cloned and sequenced. Sequence analyses indicated $>97 \%$ nucleotide sequence identity among the isolates, $94-100 \%$ identity with the previously sequenced PLYV isolate, and a lower but significant identity with sobemoviruses (43-48.5\%). These results suggest a low genetic variability among PLYV isolates, and are in agreement with the provisional placement of PLYV in the genus Sobemovirus. Definitive taxonomic conclusions, however, can only be drawn after the determination of the full-length genomic sequence.
\end{abstract}

Key words: Carica papaya, PLYV, sobemovirus.

\section{RESUMO}

Variabilidade genética de isolados do papaya lethal yellowing virus dos estados do Ceará e Rio Grande do Norte, Brasil

O mamão (Carica papaya) é uma fruta de grande importância econômica em todo o Nordeste brasileiro, região responsável por $60 \%$ da produção nacional. Mamoeiros nos estados do Ceará e Rio Grande do Norte são afetados pela doença denominada amarelo letal do mamoeiro, causada pelo papaya lethal yellowing virus (PLYV). Trabalhos anteriores indicaram que o PLYV é um possível sobemovírus. A fim de estimar a variabilidade genética do PLYV, amostras foliares de mamoeiro foram coletadas em outubro de 2008 e de 2009 em regiões produtoras do Ceará, e Rio Grande do Norte. Oligonucleotídeos específicos baseados na sequência de um isolado de PLYV previamente caracterizado foram utilizados para a amplificação via RT-PCR de um fragmento com 900 pb, correspondente à região central do genoma viral. Fragmentos de 21 isolados virais foram clonados e sequenciados. A análise das sequências de nucleotídeos indicou $>97 \%$ de identidade entre os isolados, entre 94-100\% com o isolado de PLYV previamente sequenciado, e uma identidade baixa, porém significativa, com sobemovírus (43-48,5\%). Estes resultados sugerem um baixo grau de variabilidade genética entre isolados de PLYV, e estão de acordo com a classificação provisória do PLYV como membro do gênero Sobemovirus. Conclusões de ordem taxonômica, no entanto, só podem ser tiradas após a determinação da sequência genômica completa.

Palavras-chave: Carica papaya, PLYV, sobemovírus.

\section{INTRODUCTION}

The papaya (Carica papaya L.) is a fruit crop of great economic importance in tropical and subtropical countries of the world. Papaya cultivation is widely distributed throughout the tropical regions of the world, extending to

*Present address: Universidade Estadual do Ceará, Itapipoca CE, 62500-000, Brazil.

\# Present address: Departamento de Agronomia, Universidade Estadual do Piauí, Picos PI, 64600-000, Brazil. $32^{\circ}$ latitude North and South, with the possible introduction into Brazil in 1587 (Serrano \& Cataneo, 2010). According to the Food and Agriculture Organization of the United Nations (FAO), the world production of papaya represents $10 \%$ of all tropical fruits, yielding around 8 million tons, of which $39 \%$ are produced in Latin America and the Caribbean (faostat.fao.org). The world's leading producers are India, Brazil, Nigeria, Indonesia and Mexico. In 2008, Brazil produced 1.89 million tons on 36,500 hectares with a production value estimated at U\$ 1 billion. The major papaya producer states are Bahia (902,000 tons), Espírito 
Santo (630,000 tons), Rio Grande do Norte (106,000 tons) and Ceará (100,000 tons) (Quintino, 2007; Cruz, 2008).

In most states of northeastern Brazil, papaya plants are affected by lethal yellowing disease, caused by papaya lethal yellowing virus (PLYV). This virus was first described in the early 1980's in the state of Pernambuco (Loreto et al., 1983). The disease was later detected in the states of Bahia (Vega et al., 1988), Rio Grande do Norte (Kitajima et al., 1989), Ceará (Lima \& Santos, 1991) and Paraíba (Camarço et al., 1996). Initial infection with the virus manifests as yellowing of the younger leaves, which later progresses to more severe symptoms of curled leaves, wilting and senescence. Green spots are commonly found on immature fruit and they turn yellow as the fruit reaches maturity (Lima et al., 2001). PLYV is mechanically transmitted and can be found in the soil (Camarço et al., 1998). The virus has never been reported anywhere else other than northeastern Brazil. PLYV has isometric particles with $c a .30 \mathrm{~nm}$ in diameter, and an estimated single-stranded positive sense RNA genome of $4.8 \mathrm{~kb}$. The single coat protein $(\mathrm{CP})$ has a molecular mass of $36 \mathrm{kDa}$. Analysis of the open reading frames (ORFs) encoding the putative RNA-dependent RNA polymerase $(\mathrm{RdRp})$ and coat protein $(\mathrm{CP})$ indicated that PLYV shares sequence similarity to viruses in the genus Sobemovirus (Kitajima et al., 1992a; Kitajima et al., 1992b; Silva et al., 1997; Nascimento et al., 2010). However, the complete viral genome has not yet been sequenced and therefore the taxonomical classification of PLYV is provisional. Besides, very few studies have been carried out on the genetic variability of PLYV isolates. To generate information on the variability of PLYV, we performed the cloning, sequencing and genetic analysis of genomic fragments of PLYV isolates from infected papaya plants in the states of Ceará and Rio Grande do Norte.

\section{MATERIAL AND METHODS}

\section{Sampling of papaya fields and preliminary viral detection}

A total of 27 C. papaya foliar samples displaying symptoms of lethal yellowing disease were collected in production regions around the cities of Acaraú (2 ${ }^{\circ} 53^{\prime} 09^{\prime \prime}$ $\mathrm{S}, 40^{\circ} 07^{\prime} 12^{\prime}$ ' W), Paraipaba (326'20” S, 39॰08'52” W) and Quixeré $\left(5^{\circ} 04^{\prime} 26^{\prime \prime} \mathrm{S}, 37^{\circ} 59^{\prime} 20^{\prime \prime} \mathrm{W}\right)$ in the state of Ceará, during October 2008, and the city of Baraúna ( $\left.5^{\circ} 04^{\prime} 48^{\prime \prime} \mathrm{S}, 37^{\circ} 37^{\prime} 00^{\prime \prime} \mathrm{W}\right)$ in the state of Rio Grande do Norte, during October 2009 (Table 1). Papaya samples from Acaraú were from cultivars from the Formosa group. All other samples were from the Solo group. Although samples were collected from plants with different ages, they were all at least one year old and in production stage. The presence of PLYV in the samples was assessed by indirect ELISA (Converse \& Martin, 1990) using a polyclonal antiserum produced at the Universidade Federal do Ceará. The samples were not tested for the presence of other papaya-infecting viruses.

\section{RNA extraction}

Total RNA was extracted from $2 \mathrm{~g}$ of infected leaf tissues by grinding in liquid nitrogen and extraction with

TABLE 1 - Isolates of papaya lethal yellowing virus (PLYV) obtained and analyzed in this study

\begin{tabular}{llll}
\hline \hline Isolate & \multicolumn{1}{c}{ Place of collection } & $\begin{array}{c}\text { Date of } \\
\text { collection }\end{array}$ & $\begin{array}{c}\text { GenBank accession } \\
\text { number }\end{array}$ \\
\hline 1 & Paraipaba, CE & Oct. 2008 & JQ394906 \\
2 & Paraipaba, CE & Oct. 2008 & JQ394907 \\
3 & Paraipaba, CE & Oct. 2008 & JQ394908 \\
4 & Paraipaba, CE & Oct. 2008 & JQ394909 \\
5 & Paraipaba, CE & Oct. 2008 & JQ394910 \\
6 & Paraipaba, CE & Oct. 2008 & JQ394911 \\
7 & Paraipaba, CE & Oct. 2008 & JQ394912 \\
8 & Quixeré (Itatinga District), CE & Oct. 2008 & JQ394913 \\
9 & Quixeré (Boa Esperança District), CE & Oct. 2008 & JQ394914 \\
10 & Quixeré (Boa Esperança District), CE & Oct. 2008 & JQ394915 \\
11 & Quixeré (Boa Esperança District), CE & Oct. 2008 & JQ394916 \\
14 & Quixeré (Oiticica dos Mirandas District), CE & Oct. 2008 & JQ394917 \\
18 & Acaraú (Irrigated Perimeter, lot C136/3C2), CE & Oct. 2008 & JQ394918 \\
19 & Acaraú (Irrigated Perimeter, lot C136/3C2), CE & Oct. 2008 & JQ394919 \\
20 & Acaraú (Irrigated Perimeter, lot C136/3C2), CE & Oct. 2008 & JQ394920 \\
21 & Quixeré (Itatinga District), CE & Oct. 2008 & JQ394921 \\
23 & Baraúnas (Velame Farm), RN & Oct. 2009 & JQ394922 \\
24 & Baraúnas (Velame Farm), RN & Oct. 2009 & JQ394923 \\
25 & Baraúnas (Velame Farm), RN & Oct. 2009 & JQ394924 \\
26 & Baraúnas (Velame Farm), RN & Oct. 2009 & JQ394925 \\
141 & Quixeré (Oiticica dos Mirandas District), CE & Oct. 2008 & JQ394926 \\
\hline
\end{tabular}


the Brazol reagent (LGC Biotecnologia), according to the manufacturer's instructions. The final RNA pellet was resuspended in $20 \mathrm{~mL}$ of nuclease-free water and stored at $-80^{\circ} \mathrm{C}$.

\section{RT-PCR, cloning and sequencing}

Viral cDNA was transcribed from $5 \mu \mathrm{l}$ of total RNA (approx. $5 \mu \mathrm{g}$ ) using a PLYV-specific reverse primer (5'-GTG TAT GGC ATA CAG TTA TC-3') which anneals at the 3'-end of the CP ORF based on the sequence of the Marco2 isolate (GU066876) (Amaral et al., 2006). Initially, the RNA, the primer (20 pmol) and nuclease-free water (to complete the volume to $12 \mu \mathrm{l}$ ) were incubated for $5 \mathrm{~min}$ at $65^{\circ} \mathrm{C}$, and quickly transferred to ice. The reaction was then completed with $4 \mu \mathrm{l}$ of $5 \times$ reaction buffer, $1 \mu \mathrm{l}$ of $10 \mathrm{mM}$ dNTP mix, $2 \mu \mathrm{l}$ of $0.1 \mathrm{M}$ dithiothreitol (DTT) and $1 \mu \mathrm{l}$ (200 units) of SuperScript III reverse transcriptase (Invitrogen) and incubated at $37^{\circ} \mathrm{C}$ for $1 \mathrm{~h}$ followed by $95^{\circ} \mathrm{C}$ for $5 \mathrm{~min}$. PCR was performed in a total volume of $50 \mu \mathrm{l}$, using $2.5 \mu \mathrm{l}$ of the cDNA, $5 \mu \mathrm{l} 10 \times$ PCR buffer (200 mM Tris-HCl, pH 8.4, 500 $\mathrm{mM} \mathrm{KCl}), 3 \mu \mathrm{l}$ of $25 \mathrm{mM} \mathrm{MgCl}_{2}, 1 \mu \mathrm{l}$ of dNTPs $(2.5 \mathrm{mM}$ each), 20 pmol of each primer [the same reverse primer used in the reverse transcription reaction plus a forward primer, 5' TGA AGC GGA TAT TTC TGG 3', which anneals at the 3'-end of the RdRp ORF (Amaral et al., 2006)] and 1 unit of Taq DNA polymerase. The thermocycler (PTC-100, MJ Research Inc.) was programmed for 35 cycles of denaturing at $94^{\circ} \mathrm{C}$ for 1 minute, primer annealing at $55^{\circ} \mathrm{C}$ for 2 minutes and extension at $72^{\circ} \mathrm{C}$ for 1 minute, with a final extension at $72^{\circ} \mathrm{C}$ for 10 minutes.

PCR products were analyzed by electrophoresis on $1 \%$ agarose gels and were purified from the gels using the GFX PCR DNA and Gel Band Purification kit (GE Healthcare) according to the manufacturer's instructions. The amplified fragments were cloned using the pGEM-TEasy kit (Promega), using the methodology recommended by the manufacturer. Cloning was confirmed by digestion of plasmid DNA with EcoR I and analysis by agarose gel electrophoresis. Viral fragments were sequenced in their entirety at Macrogen (Seoul, South Korea).

The nucleotide (nt) sequences obtained from the PLYV isolates were aligned and compared with those from 11 sobemoviruses available in GenBank (Table 2). Partial amino acid (aa) sequences for the RdRp and CP ORFs were deduced using the ORFinder tool (www.ncbi.nlm. nih.gov/projects/gorf). Pairwise sequence comparisons were performed with DNAMan v. 4 (Lynnon Biosoft). The program DnaSP v5 (Librado \& Rozas, 2009) was used to determine nucleotide sequence diversity and $\mathrm{dN} /$ dS ratios. Multiple sequence alignments were obtained with Clustal W (Thompson et al., 1994). Phylogenetic trees were constructed with MEGA 5.0 (Tamura et al., 2011), using the neighbour-joining algorithm with 2,000 bootstrap replications.

\section{RESULTS AND DISCUSSION}

\section{Cloning of PLYV genomic fragments}

Out of 27 papaya samples collected in Rio Grande do Norte and Ceará states, 21 were positive for the presence of PLYV based on results of indirect ELISA using a PLYV-specific polyclonal antiserum (data not shown). An approximately 900 bp DNA fragment was successfully amplified via RT-PCR from total RNA extracted from these 21 samples, cloned and completely sequenced (Table 1).

\section{Sequence comparisons}

A preliminary analysis of the sequences using BLASTn (Altschul et al., 1990) indicated the PLYV Marco2 isolate (GenBank access number GU066876) as the closest related virus, with $>94 \%$ nt sequence identity with all isolates (data not shown). Further analysis using the

TABLE 2 - Viruses used for nucleotide and amino acid sequence alignments, comparisons and construction of phylogenetic trees. All viruses belong to the genus Sobemovirus, except where indicated

\begin{tabular}{lc}
\hline \hline Virus & GenBank accession number \\
\hline Papaya lethal yellowing virus (PLYV) - Marco2 ${ }^{\mathrm{a}}$ & GU066876 \\
Southern bean mosaic virus (SBMV) & AF055887 \\
Sesbania mosaic virus (SeMV) & AY004291 23021 \\
Southern cowpea mosaic virus (SCPMV) & Z48630 \\
Cocksfoot mottle virus (CfMV) & $\mathrm{U} 31286$ \\
Lucerne transient streak virus (LTSV) & L20893 \\
Rice yellow mottle virus (RYMV) & AF208001 \\
Subterranean clover mottle virus (SCMoV) & AY177608 \\
Turnip rosette virus (TRoV) & AB040446 \\
Ryegrass mottle virus (RGMoV) & AM940437 \\
Rubus chlorotic mottle virus (RuCMV) & AM990928 \\
Imperata yellow mottle virus (IYMV) & D00530 \\
Potato leafroll virus (PLRV) & b
\end{tabular}

\footnotetext{
${ }^{\text {a }}$ Possible sobemovirus, partial sequence.

${ }^{\mathrm{b}}$ Gen. Polerovirus, Fam. Luteoviridae; used as an outgroup.
} 
ORF finder tool indicated that the $900 \mathrm{bp}$ fragment included two partial ORFs in the same sense, one corresponding to a putative viral RNA dependent RNA polymerase (RdRp) and the other corresponding to the viral coat protein (CP). Nucleotide sequence identities for the RdRp ORF of all isolates were $>93 \%$ with PLYV Marco2, and for the CP ORF were $>94 \%$ (Table 3). Together, these results confirmed the identification of all 21 isolates as PLYV.

Pairwise comparisons indicated that the $900 \mathrm{bp}$ fragments amplified from the 21 viral isolates shared $>97 \%$ nt sequence identity amongst themselves (data not shown). Separate comparisons for the RdRp and CP ORFs indicated nt identities $>94 \%$ and $>95 \%$, respectively, amongst the 21 isolates (Table 3). These results are equivalent to those observed for the sobemovirus Rice yellow mottle virus (RYMV), for which the average nt diversity for the full genomic sequences of 16 isolates was $7 \%$, and the maximum diversity between any two isolates was $10 \%$ (Fargette et al., 2004). Considering that some of the locations where the samples were collected are approximately $370 \mathrm{~km}$ apart, that samples were collected within a one-year interval (Table 1), and that the $\mathrm{dN} / \mathrm{dS}$ ratios for the RdRp and CP ORFs were 0.108 and 0.185 , respectively, the genetic variability of the virus can be considered to be low.

PLYV was first recognized in the 1980's (Loreto et al., 1983), and has always been restricted to a relatively small geographical area (ie, it has never been reported anywhere else). Therefore, the odds of the virus having been introduced from another region are low. Most likely the virus was present in wild hosts and jumped to payaya plants once this crop became widely cultivated in that area. If that is the case (but it should be clear that no evidence is available to support this hypothesis), then it is reasonable to assume that multiple "host jumping" events could have occurred, and the genetic base of the viral population in papaya plants would not necessarily be narrow. Interestingly, a vector has not yet been found for PLYV, and it has been suggested that the virus may not have one (Camarço et al., 1998). Vector transmission is a notorious genetic bottleneck. Should a mode of transmission which does not impose a genetic bottleneck (eg, through soil) be demonstrated, this would provide further evidence against a founder effect acting upon the viral population in papaya plants. The low genetic variability detected here could therefore be a feature of this virus.

Sequence comparisons with known sobemoviruses indicated that the putative RdRp of PLYV is much more similar to the corresponding protein of sobemoviruses than the CP (Table 4). In addition, motifs in nucleotide and deduced amino acid sequences of sobemovirus proteins are also present in the PLYV sequences (data not shown), reinforcing the relationship between PLYV and other members of the genus Sobemovirus.

The deduced amino acid sequences of the RdRp showed the greatest identity with the sobemoviruses Subterranean clover mottle virus (SCMoV; 84\%), Turnip rosette virus (TRoV) and Lucerne transient streak virus (LTSV) (83\% in both cases), and Ryegrass mottle virus (RGMoV; 81\%) (Table 4). Identity values for the deduced amino acid sequence of the CP were $35 \%$ with Southern cowpea mosaic virus (SCPMV) and 33\% with Southern bean mosaic virus (SBMV) (Table 4). However, a closer examination of Table 4 indicates that the CP of sobemoviruses is much more variable than the RdRp. Except for the CPs of SBMV, SCPMV and Sesbania mosaic virus (SeMV), which share $65-77 \%$ identity, those of other sobemoviruses share only $8-40 \%$ identity (Table 4 ). Identity values for the RdRps vary from 36 to $82 \%$ (Table 4). Therefore, the identity values observed between the PLYV CP and those from other sobemoviruses is within the normal range for this group of viruses.

As it had been previously suggested that PLYV could be a member of the genus Tombusvirus, we also performed sequence comparisons with tombusviruses as well as viruses in other genera of the family Tombusviridae. The greatest identity values observed were $13 \%$ for the RdRp and $17 \%$ for the CP of Tomato bushy stunt virus (TBSV) (data not shown). The identity values for the RdRp are much lower than those observed with sobemoviruses. While the identity values observed for the $\mathrm{CP}$ are within the same range observed among sobemoviruses, it must be noted that the CPs of sobemoviruses and necroviruses (genus Necrovirus, family Tombusviridae) are known to be distantly related, with an early recombination event being suggested to be involved in the evolution of these genera (Truve \& Fargette, 2011).

\section{Phylogenetic analysis}

Results of phylogenetic analysis corroborate those of sequence comparisons. A phylogenetic tree based on the nucleotide sequence of the $900 \mathrm{bp}$ fragment shows that all 21 isolates obtained from Ceará and Rio Grande do Norte states are closely related to each other as well as to the Marco2 isolate, with RGMoV being the closest sobemovirus (Figure 1). Trees based on the amino acid sequences of the CP and RdRp had similar topologies (data not shown).

Together, the results of sequence comparisons and phylogenetic analyses indicate that PLYV is much more closely related to sobemoviruses than to tombusviruses, and are consistent with the classification of PLYV as a species in the genus Sobemovirus. However, the sequenced fragment represents only aproximately $25 \%$ of the viral genome. Furthermore, the number of complete sobemovirus sequences is low, and therefore it is difficult to state which region of the genome (if any) could be representative of the entire genome (Truve \& Fargette, 2011). The study by Fargette et al. (2004) indicates that the $\mathrm{CP}$ is quite variable (our data shows the same) but at the same time, phylogenetic trees based on the entire genome or the $\mathrm{CP}$ sequence have very similar topologies. Therefore, at least for RYMV, the CP sequence can be used to type isolates. 
Genetic variability of papaya lethal yellowing virus isolates from Ceará...
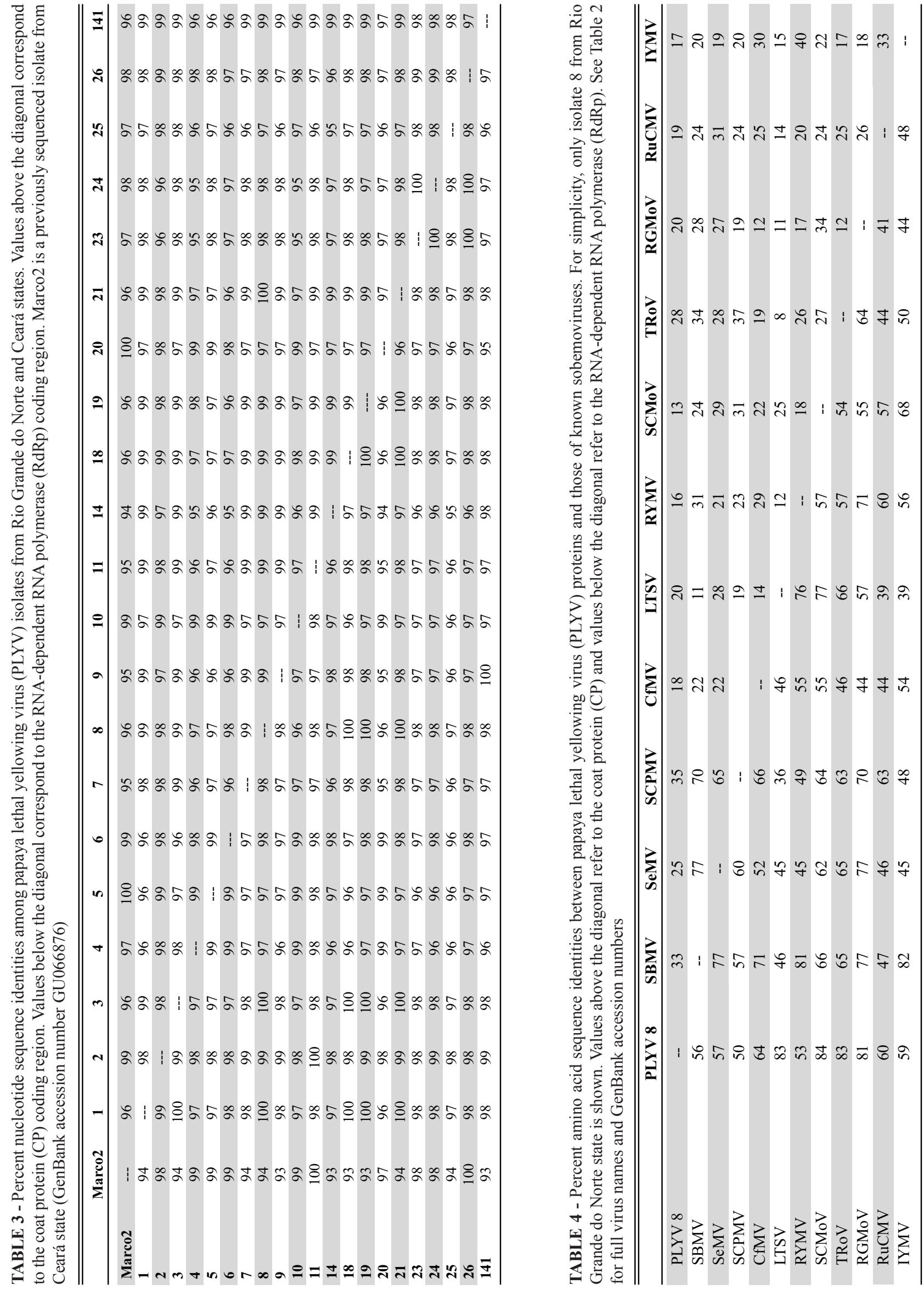


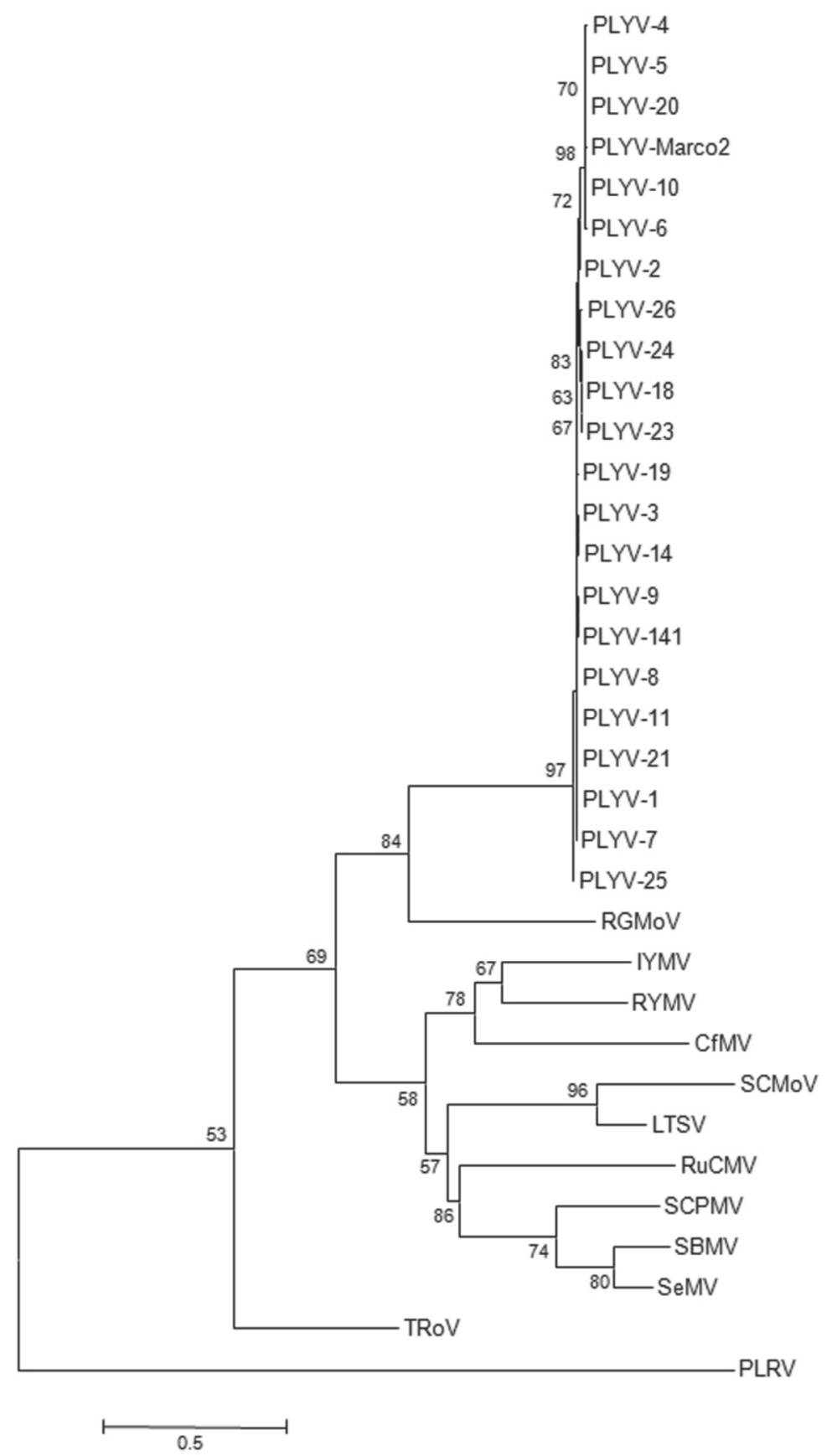

FIGURE 1 - Phylogenetic tree based on the nucleotide sequence of a 900 bp fragment, encompassing part of the putative RdRp and $\mathrm{CP}$ open reading frames, from 21 isolates of papaya lethal yellowing virus (PLYV) from Ceará and Rio Grande do Norte states, Brazil, and viruses in the genus Sobemovirus. Potato leafroll virus (genus Polerovirus, family Luteoviridae) was included as an outgroup. The tree was constructed using the neighborjoining method and the $\mathrm{K} 2+\mathrm{I}+\mathrm{G}$ nucleotide substitution model, and was bootstrapped with 2000 replications. See Table 2 for full virus names and GenBank accession numbers.
In any event, a definitive taxonomic placement for PLYV will require the determination of its complete genomic sequence, since it is not unreasonable to assume that the remaining part of the genome could be divergent from known sobemoviruses.

\section{ACKNOWLEDGEMENTS}

This work was partially funded by Conselho Nacional de Desenvolvimento Científico e Tecnológico CNPq (grant 474137/2007-4) to ECA.

\section{REFERENCES}

Altschul SF, Gish W, Miller W, Myers EW, Lipman DJ (1990) Basic local alignment search tool. Journal of Molecular Biology 215:403-410.

Amaral PP, Resende RO, Sousa Junior MT (2006) Papaya lethal yellowing virus (PLYV) infects Vasconcellea cauliflora. Fitopatologia Brasileira 31:517.

Camarço RFEA, Lima JAA, Pio-Ribeiro G (1998) Transmissão e presença em solo do papaya lethal yellowing virus. Fitopatologia Brasileira 23:453-458. 
Camarço RFEA, Lima JAA, Pio-Ribeiro G, Andrade GP (1996) Ocorrência do "papaya lethal yellowing virus" no município de Santa Rita, Estado da Paraíba. Fitopatologia Brasileira 29:423.

Converse RH, Martin RR (1990) Elisa methods for plant viruses. In: Hampton R, Ball E, Boer Sd (Eds.) Serological methods for detection and identification of viral and bacterial plant pathogens. APS Press. pp. 179-196.

Cruz JL, <http://www.infobibos.com/Artigos/2008_1/mamao/ index.htm $>(15 / 01 / 2008)$

Fargette D, Pinel A, Abubakar Z, Traoré O, Brugidou C, Fatogoma S, Hébrard E, Choisy M, Séré Y, Fauquet F, Konate G (2004) Inferring the evolutionary history of Rice yellow mottle virus from genomic, phylogenetic, and phylogeographic studies. Journal of Virology 78:3252-3261.

Kitajima EW, Oliveira FC, Pinheiro CSR, Soares LM, Pinheiro K, Madeira MC, Chagas M (1992a) Amarelo letal do mamoeiro Solo no estado do Rio Grande do Norte. Fitopatologia Brasileira $17: 282-285$.

Kitajima EW, Oliveira FC, Pinheiro CSR, Soares LM, Pinheiro K, Vasconcelos MF (1989) Ocorrência do vírus do amarelo letal do mamoeiro no estado do Rio Grande do Norte. Fitopatologia Brasileira 14:164.

Kitajima EW, Rezende JAM, Vega J, Oliveira CRB (1992b) Confirmada identidade do vírus isométrico encontrado em mamoais do Rio Grande do Norte como sendo o do amarelo letal do mamoeiro Solo. Fitopatologia Brasileira 17:336-338.

Librado P, Rozas J (2009) DnaSP v5: A software for comprehensive analysis of DNA polymorphism data. Bioinformatics 25:14511452 .

Lima JAA, Santos CDG (1991) Isolamento de possível estirpe do vírus do amarelo letal do mamoeiro no Ceará. Fitopatologia Brasileira 16:27.

Lima RCA, Lima JAA, Souza JR. MT, Pio-Ribeiro G, Andrade GP (2001) Etiologia e estratégias de controle de viroses do mamoeiro no Brasil. Fitopatologia Brasileira 26:689-702.

Loreto TJG, Vital AF, Rezende JAM (1983) Ocorrência de amarelo letal do mamoeiro solo no estado de Pernambuco. O Biológico 49:275-279.

Nascimento AKQ, Lima JAA, Nascimento ALL, Beserra Jr. JE, Purcifull DE (2010) Biological, physical, and molecular properties of a papaya lethal yellowing virus isolate. Plant Disease 94:12061212.

Quintino HMS (2007) Benefícios sociais da política de incentivos à cultura do mamão no Estado do Ceará. Dissertação MS. Universidade Federal do Ceará. Fortaleza, CE.

Serrano LAL, Cataneo LF (2010) O cultivo do mamoeiro no Brasil. Revista Brasileira de Fruticultura 32:657-959.

Silva AMR, Kitajima EW, Sousa MV, Resende RO (1997) Papaya lethal yellowing virus: a possible member of the Tombusvirus genus. Fitopatologia Brasileira 22:529-534.

Tamura K, Peterson D, Peterson N, Stecher G, Nei M, Kumar S (2011) MEGA5: Molecular evolutionary genetics analysis using maximum likelihood, evolutionary distance, and maximum parsimony methods. Molecular Biology and Evolution 28:27312739.

Thompson JD, Higgins DG, Gibson TJ (1994) CLUSTAL W: Improving the sensitivity of progressive multiple sequence alignment through sequence weighting, position-specific gap penalties and weight matrix choice. Nucleic Acids Research 22:4673-4680.

Truve E, Fargette D (2011) Genus Sobemovirus. In: King AMQ, Adams MJ, Carstens EB, Lefkowitz EJ (Eds.) Virus Taxonomy. 9th Report of the International Committee on Taxonomy of Viruses. London, UK. Elsevier Academic Press. pp. 1185-1189.

Vega J, Bezerra JL, Rezende MLV (1988) Detecção do vírus do amarelo letal do mamoeiro solo no estado da Bahia através de microscopia eletrônica. Fitopatologia Brasileira 21:147. 